\title{
評価グリッド法におけるハイブリッド型の調査デザインの検討 環境心理評価における定性調査手法の研究 その 2 \\ A STUDY ON THE HYBRID DESIGN OF RESEARCH FOR EVALUATION GRID METHOD
}

A study on qualitative research for getting evaluation term Part2

\author{
彭博*1, 小島隆矢*2 \\ Bo PENG and Takaya KOJIMA
}

\begin{abstract}
Previous paper showed that evaluation grid method had high interpretability, triadic procedure technique had moderate interpretability while typical free description had low interpretability. Based on the results of our previous paper, this paper proposes the hybrid design for evaluation grid method which combine the evaluation grid method with typical free description. The hybrid design for evaluation grid method has three merits: 1) sampling a target person for interview, 2) reducing interview time, 3) inspecting and completing evaluation terms by the date of typical free description and 4) being easier facilitating to interpret evaluation structures.
\end{abstract}

Keywords : Evaluation grid method, Evaluation structure, Typical free description, Questionnaire, Cluster analysis, Sampling 評価グリッド法, 評価構造, 定型自由記述, アンケート調查, クラスター分析, サンプリング

\section{1.はじめに}

環境心理研究の分野では，評価グリッド法をはじめとする定性調 査の重要性が認識されるようになって久しい。本研究では, 定性調 查をより有効に活用できるような知見を得るため，既存手法につい て，その特徴を活かした活用法の提案や改良も視野に入れた手法研 究を行っている。前報 ${ }^{3)}$ では, 評価グリッド法・レパートリーグリ ッド法（3 個組法）・定型自由記述（のでから法）という3つの定性 調查手法について, 抽出される評価語の総合評価に対する説明力と いう観点から比較研究を行った。その結果として, 評価グリッド法 は, 総合評価に対する説明力の高い評価語が 3 手法の中で最も多く 抽出され, 次に 3 個組法, そして定型自由記述という順であった。

本報では, 前報より説明力が高いと実証された評価グリッド法と, 説明力はそれほどでもないが大規模調查が可能な定型自由記述に着

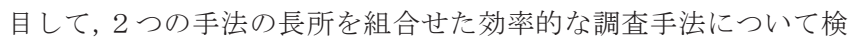
討・提案する。

\section{2. 本研究の目的および論文の構成}

評価グリッド法は提案 ${ }^{4)}$ 当初より「予備調查的性格を持つ」とさ れる一方で, その実学的有用性から評価グリッド法の結果自体を目 的とする調査も多い。また, 評価グリッド法は個別インタビューで あるため調查可能人数には限界があり, 十〜数十名程度の場合が大 半である。予備調査としては大きな問題はないとしても, 評価グリ ッド法の結果自体を目的とする場合，この人数で十分であるかが镙
念される。

定型自由記述（のでから法）については，前報より評価グリッド 法の簡易化代替となりうるか注目されたが，3手法の中でも総合評 価に対する説明力は最も低く, 説明力という点では評価グリッド法 に全く振るわない結果となった。しかし, 定型自由記述はアンケー ト形式の調査であるため, 大規模調査が可能という点に関してはと ても魅力的であり，この特徴を活かすことはできないかと考える。

このような背景から, 本報では, 大人数への調查が容易なアンケ 一ト用紙等による定量調查を予備調査的な位置づけとしてまず行い, その結果をもとに評価グリッド法の調查対象者を計画的にサンプリ ングし, 最終的に, 定性調查である評価グリッド法をより効率的に 実施する方法を検討・提案することを目的とする。以下，本報で提 案・検討する，このような手順で行う調査を，評価グリッド法にお けるハイブリッド型の調査デザインと呼ぶこととする。

本論文の構成を述べる。続く 3 章で評価グリッド法におけるハイ ブリッド型の調査デザインの概要について述べ，4 章および 5 章で 適用事例を報告する。そして 6 章で評価グリッド法におけるハイブ リッド型の調査デザインの有効性について述べ， 7 章でまとめと今 後の予定など総括を行う。

\section{3. 評価グリッド法におけるハイブリッド型の調査デザインの概要}

評価グリッド法におけるハイブリッド型の調査デザインの概要を 図 1 に示す。通常, 評価グリッド法はエレメントを準備し比較して,
$* 1$ 早稲田大学大学院人間科学研究科 修士 (人間科学)

*2 早稲田大学人間科学学術院 教授・博士 (工学)
Grad. Student, Grad. Sch. of Human Sciences, Waseda Univ., M.A. in Human Sciences Prof., Faculty of Human Sciences, Waseda Univ., Dr.Eng. 
オリジナル項目を抽出しラダーリングによって評価構造を作成する という流れで行われる。これらは個別のインタビュー形式で行われ ることが多く, 調查時間やコストがかかり, 調查可能人数にも限界 がある。そこで，本報で試みる調査デザインの特徴は以下のように なっている。

(1)アンケート調査で実施できる部分はアンケート調査で代替し, 比 較的手間のかかるインタビュー調査の占める割合を減らす。

(2)評価グリッド法の調查対象者を計画的にサンプリングすること

で，少ない調査人数でも調査結果の網羅性・代表性を確保する。

(1)について, 選好度評価と評価理由の抽出をアンケート形式の調 査で代替する。アンケート調査によって抽出された評価理由の項目 はオリジナル項目となる。それにより, インタビュー調查を始める 前に, ある程度のオリジナル項目が抽出され, インタビュー調查に おいてはラダーリングから始めることが可能となり, 結果としてイ ンタビュー形式の調査にかける時間を短縮することができる。さら に，選好度評価の結果より，(2)評価グリッド法の調査対象者を事前 に計画的にサンプリングすることも可能となり, 調査人数が数十程 度であっても調査結果の網羅性・代表性を確保することができる。 以下，調査の手順など詳細について示す。

\section{口準備 I：エレメントの準備}

エレメントの準備について, 対象者に記憶の中から想起してもら う場合と, 調査者が準備する場合がある。エレメントの数に関して は，対象者にエレメントを挙げてもらう場合は 10 前後が目安であ る。一方, 調查者がエレメントを準備する場合は, 30〜 40 のエレメ ントを用いることもある。いずれにしても 30 以下にしておくことが 好ましいとされている5）6)。

エレメントの数が 30 程度のときはそのまま調査に用いても問題 はないが，30 以上あるとき，これら全てを評価対象とすることは情 報過多により却って混乱を招くことが懸念される。そこで, より円 滑に調査を行うためにエレメントの数を減らす作業を行うことがあ る。エレメントの分類・選定の作業については, エレメントをイメ ージ・印象により分類してグループを作成し, 各グループから数枚 ずつエレメントを選び，以後の調査に用いるというような方法が考 えられる7)。なお，このエレメントの分類・選定の作業に関しては， 調査を開始するにあたっての準備の一環として調査者が行う場合と， 予備調查的位置づけとして対象者が行う場合がある。

口調査 I : アンケート調査（選好度評価および定型自由記述）

アンケート調查により, 選好度評価および評価理由の抽出を行う。 選好度評価については，5段階（好ましい(5)〜好ましくない(1)） で行い, 評価理由の抽出については,「のでから」形式など定型自由 記述式設問で行う。なお, アンケート調査の対象者は, 準備 I でエ レメント数が 30 以上あった場合で, 予備調査的位置づけとしてエレ メントの分類・選定の作業を行った対象者と同一でなくて良い。

口準備 II：インタビュ一調査対象者の選定・編成

調査 I の選好度評価の結果より, 回答者を選好度によりクラスタ リングして評価グリッド法を準用したインタビュー調查を実施する 対象者の選定を行う。評価グリッド法の調查対象者を計画的にサン

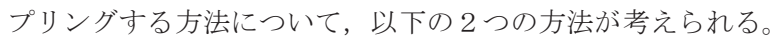
方法 1 : 多様な層から網羅的に対象者を選出

選好度による回答者のクラスタリングを行い, 各クラスターから

一定数の対象者を選ぶ。すなわち, 様々な選好傾向を持つ人から幅 広く網羅的に意見を抽出するということである。

方法 2 : 特定の層から集中的に対象者を選出

選好度による回答者のクラスタリングを行い，特定のクラスター から一定数の対象者を選ぶ。すなわち, 特定の選好傾向を持つ人の みに絞って意見を抽出するということである。

4 章にて, 方法 1 : 多様な層から網羅的に対象者を選出する事例 を，5章にて，方法 2 : 特定の層から集中的に対象者を選出する事 例を報告する。

ロ調査 II：インタビュ一調査（評価グリッド法）

評価グリッド法を準用したインタビュー調查を行う。調查 I の定 型自由記述において, 評価の理由についてはすでに抽出されている ため，その項目をオリジナル項目として用いる。ここでは，オリジ ナル項目を起点としたラダーリングに重点を置いて, インタビュー を進めていく。

\section{4. 多様な層から網羅的に対象者を抽出した事例}

\section{1 適用事例：庭空間に関する意識調査}

本事例では, エクステリア関連総合メーカーの協力のもと,「庭空 間」へのニーズ把握調査を行った。対象者は大学(院)生であり, 調 查期間は 2014 年 11 月〜 12 月である。

\section{2 調査の手順}

1 ）印象による庭空間の分類・選定（回答者による）

$\left(\mathrm{Web}^{8)}\right.$ に掲載されている庭施工例写真 60 枚を 12 名 (男女各 6 名) に提示し, 庭の印象に基づくグループ作成および各グループの特徵 を表す評価語抽出の作業を個人別に行った。グループ数に制限は設 けなかったが, 1 人あたり 5〜12,のべ 94 のグループが作成された。 その結果を, 60 枚の庭写真を観測個体, 評価者 12 名をアイテム, 各評価者が作成したグループをカテゴリー（その評価語はカテゴリ 一名称）として数量化 III類 ${ }^{9}$ ) を適用した。第 5 軸まで（累積寄与率 38\%) の庭スコアをもとにクラスター分析を行い, 12 名の印象による 分類を統合した 7 クラスターを得た。各 1〜2 枚, 計 12 枚の庭写真 を選定し, 以後の調查の評価対象として用いる。

\section{2 ) アンケート調査による選好度評価および評価理由の抽出}

12 枚の庭写真を評価対象として, 選好度評価（好ましい(5)～好ま しくない(1)) およびその評価理由を下記の形式 (所謂「のでから法」)

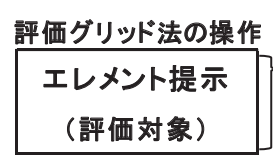

（評価対象）

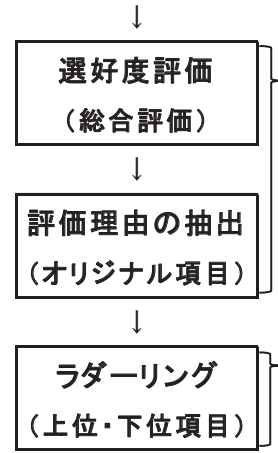

図 1 評価グリッド法におけるハイブリッド型の調査デザインの概要
実査モードのハイブリッド化
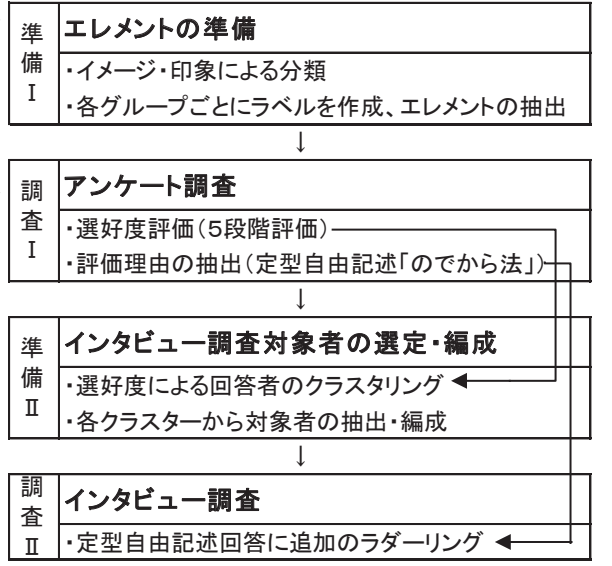
で回答する定型自由記述式設問によるアンケート調查を行った。

（）ので（）から（好ましい・好ましくない）

庭写真の提示に際して, 提示の順番による影響をなくすために, 12 枚の写真をランダム化し, アンケート用紙を 4 パターン作成して 調査を行った。また，「のでから」の定型 自由記述式設問では，全てのエレメント について 1 件 ( 1 文: 記入欄は $2 つ)$ 以上 の記述を求めているため, 回答者 1 名に つき 12 エレメントメ記入欄 $2 つ=24$ 個 以上の記述を得ている。

3 ) 選好度評価による回答者のクラスタ リング

有効回答は 77 名（男 31 女 38 性別無回 答 8）であった。選好度評価の結果を 12 の庭を観測個体，77 名の回答者を変数と して主成分分析を行い, さらに因子負荷 量をもとに回答者のクラスター分析を行 う。第 5 主成分までを採用し（累積寄与 率 $68.6 \%$ ，共通性が 0.4 未満の 6 名を除 外して 71 名を対象に k-maens 法を実行し たところ，10１4 名ずつ 6 つのクラスタ 一（C1〜C6）を得た。

4 ) 回答者クラスター別の評価グリッド 法（各クラスターから一定数ずつ対象者 を抽出し評価グリッド法を実施）

3 ) で得られた回答者クラスターから 各 2 3 名, 計 15 名を調査対象者として 抽出し, 評価グリッド法を準用したイン タビュー調査を行った。ただし2)より選 好度評価とその理由はすでに抽出済みで あるため，各個人のその結果を整理した メモを提示し不明点の確認と評価理由の 追加を必要に応じて行った後，ラダーリ ングの操作のみ集中的に行うという手順 をとった。調査結果に基づき，各個人およ びクラスターごとに評価構造図を作成し た。

\section{3 結果と考察}

結果出力の例として, 図 2 はクラスタ - 3 に該当する 2 名分の評価構造図をま とめたもの, 図 3 はクラスター 6 に該当 する 2 名分の評価構造図をまとめたもの を示している。図中, インタビュー実施者 2 名に共通する項目を太枠で示し，調査 I（アンケート調查）の定型自由記述も含 めた同一クラスター内の，ほぼ同様の概 念とみなせる項目の使用人数を括弧内に 示した。調查 I の回答者を含めれば, 大半 の項目が同一クラスター内の複数名に用 いられている。各クラスター 2 名ずつと
いうのは非常に倹約的なインタビュー調査の計画であるが，その抽 出母体となるアンケート調査の各 11 名のデータから, そのクラスタ 一において得られた項目がある程度共有されていることを確認でき たことになる。

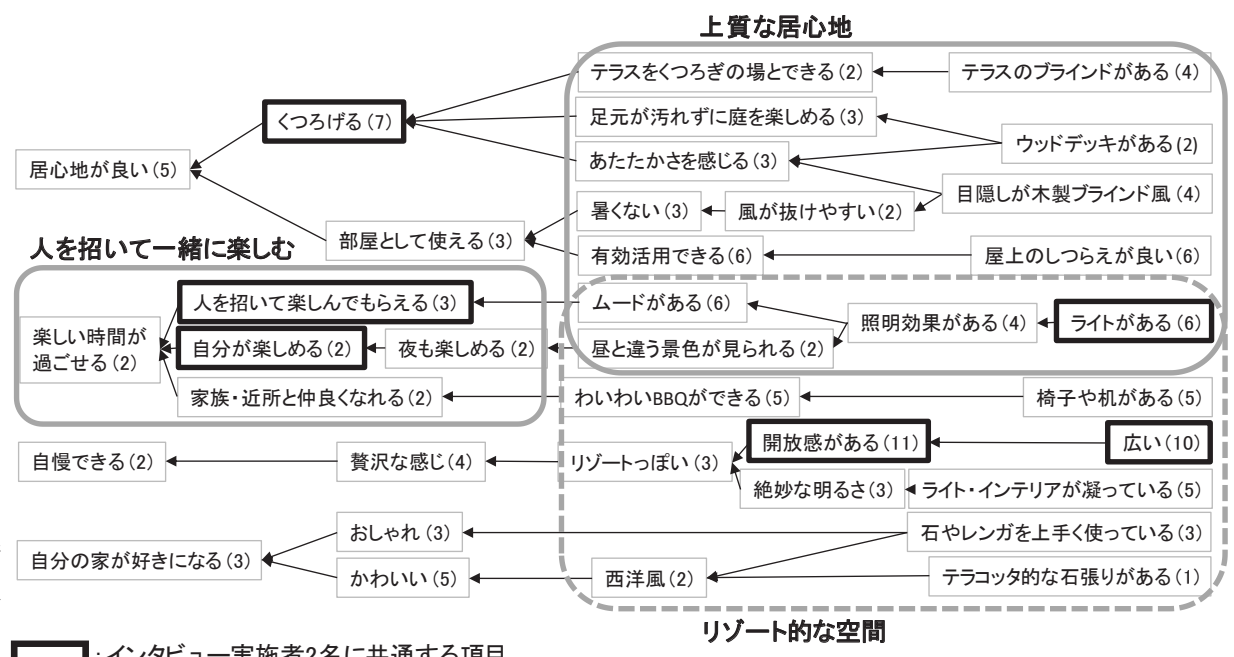

: インタビュ一実施者2名に共通する項目

リゾート的な空間

) 内 : 調査 I (アンケート)の定型自由記述も含めた同一クラスタ一内の, ほぼ同様の概念とみなせる項目の使用人数 図 2 評価構造図（クラスター3）

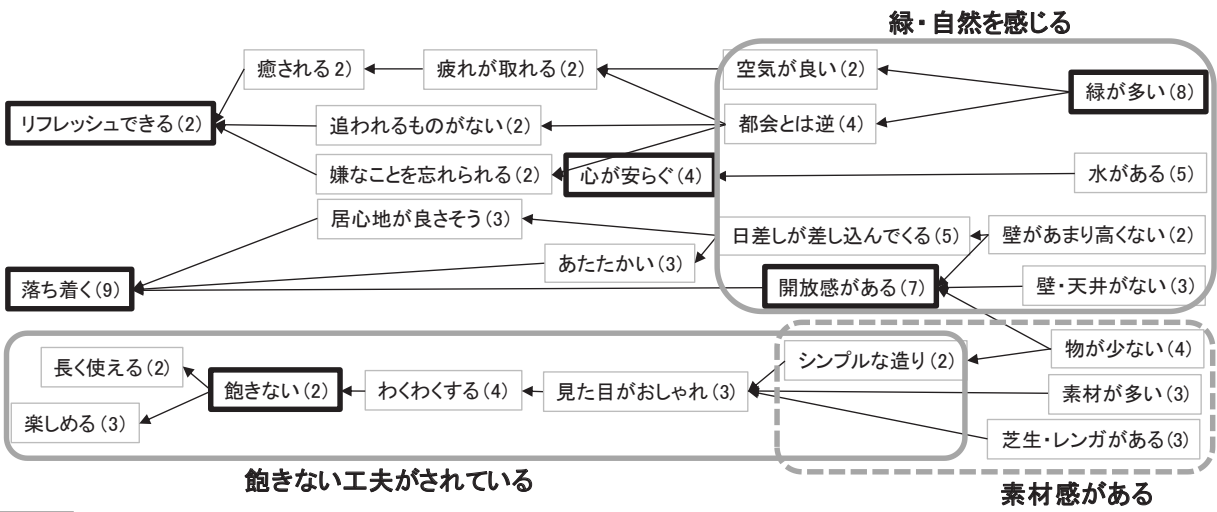

: インタビュ一実施者2名に共通する項目

) 内: 調査 I (アンケート)の定型自由記述も含めた同一クラスター内の, ほぼ同様の概念とみなせる項目の使用人数 図 3 評価構造図（クラスター6）

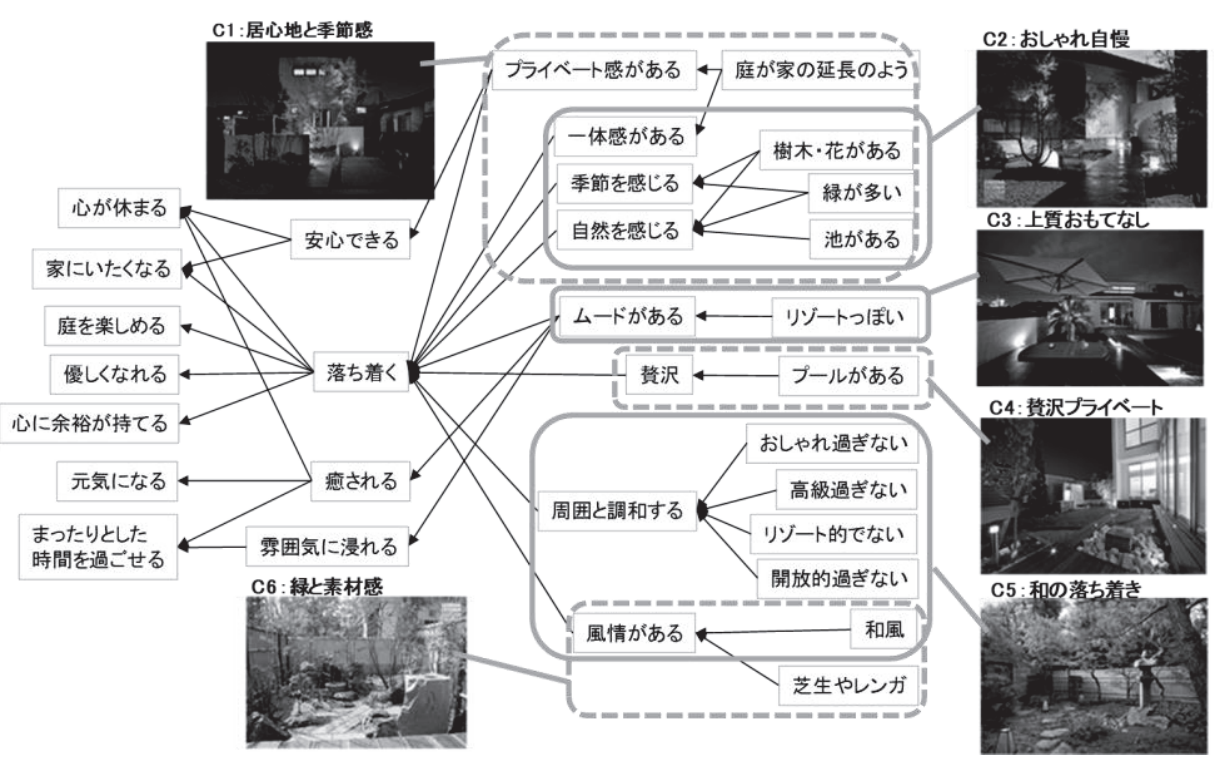

図 4 「落ち着き」に関する評価構造図（クラスター1～6 ) 
以下，各クラスターの評価構造図を解釈する。クラスター 3 から は，「上質で居心地の良い空間でくつろぎたい」，「人を招いて楽しい 時間を過ごしたい」というニーズ, クラスター 6 からは,「緑が多く, 素材にこだわっていて飽きない工夫がされている空間で心を休めリ フレッシュしたい」というニーズが抽出された。得られた評価構造 は，クラスターごとにかなり異なる特色を有するものとなった。同 一クラスター内にも個人によるバリエーションがあるが，同一概念 として共有されるニーズが読み取れる。一見, 多くのクラスターに 共通するニーズ項目として「落ち着き」が挙げられる。どのような 庭でどのように落ち着くかはクラスター間で異なる。各クラスター から「落ち着き」に関する項目を抽出し図 4 を作成した。図 4 より, C1 は住居の延長のような落ち着きを, C3 は人を招いて上質な時間を 共有するためのリゾート的・贅沢な落ち着きを求める。C4 は C3 と 似ているが，よりプライベートな日常の落ち着きを求める。C5, C6 は おしやれ・高級・リゾート的だと落ち着かず，C5 は周囲と調和した 和風の風情, $\mathrm{C} 6$ は緑が多く芝生や煉瓦など素材感により落ち着きを 感じる。C2 はおしゃれで美しいスタイリッシュな庭を求め, 優越感 や記憶に残るシンボル性を重視しており「落ち着き」は（一応，抽 出されたものの) あまり重視していないようである。

\section{5. 特定の層から限定的に対象者を抽出した事例}

\section{1 適用事例：オフィス空間に関するニーズ調査}

本事例では，オフィス空間に対するワーカーのニーズについて， 次のような観点から調査を行った。まず，様々なタイプのオフィス の中でも特に, オフィスコストの面では対極に位置する 2 つのタイ プとして，作業可能な机と椅子が揄った最低限のものしかない環境 である「ミニマム」なオフィスと, 空間の色彩やデザインを重視し た環境である「高付加価值」なオフィスを取り上げ，それぞれの才 フィスを選好する層が感じる魅力（どのような魅力があるか・どの ようであれば魅力があるか）を中心に，両タイプを比較しつつニー ズの構造を把握寸るための調査を行った。対象者は 20 代〜60 代ま での社会人であり，調查期間は 2015 年 10 月〜 12 月である。

\section{2 調査の手順}

\section{1 ) オフィスの分類・選定（調査者による）}

ミニマムオフィスに該当する写真を 6 枚, 高付加価值オフィスに 該当する写真を 6 枚，その他の（ミニマムオフィスでも高付加価值 オフィスでもない）オフィスの写真を８枚，調査者によって選定さ れた計 20 枚のオフィス写真 ${ }^{10)}$ を評価対象として用いる。

\section{2 ) アンケート調査による選好度評価および評価理由の抽出}

20 枚のオフィス写真を評価対象として, 選好度評価（好ましい(5) 〜好ましくない(1)) およびその評価理由の抽出を行った。具体的な 手続きとしては, まず全てのエレメントに対して選好度評価を行い, 次に回答者が好ましい・好ましくないと評価するオフィスについて, 評価理由の記述を行う形式とした。その際，個々の評価理由は好ま しい・好ましくないと評価したオフィスの全てに当てはまる必要は なく，いくつか（特定の 1 つでも可）のオフィスに当てはまる理由 でも構わないものとし，どのエレメントに対する好ましい・好まし くない理由かというエレメントの特定は行わなかった。これは本来 の評価グリッド法におけるオリジナル項目を抽出する過程までを極 力踏襲した手続きを意図している。定型自由記述の形式については
「のでから」形式ではなく, 回答が長くなりすぎないよう短いコメ ント闌を設ける形式で行い, 回答者 1 名につき好ましい・好ましく ない理由の記述をそれぞれ 7 件以上得ている。

\section{3) 選好度評価による回答者の分類とインタビュ一対象者の抽出}

有効回答は 63 名（男 35 女 28）であった。回答者をミニマムオフ ィスを好む人，高付加価值オフィスを好む人，その他のオフィスを 好む人に分類する。ミニマムオフィスまたは高付加価值オフィスを 表すダミ一变数（該当：1, 非該当：0）を作成し，回答者ごとに選好

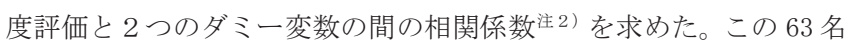
分の相関係数の分布を図 5 に示す。図 5 の分布の形より, 相関係数 が概ね 0.25 以上の領域に各オフィスを好む回答者が一群の部分母 集団を形成しているように見える。インタビュー調査の対象者はこ の層から選出することを意図して, 相関係数が高い人から順に調査 を依頼した。結果的にミニマムオフィスは 0.296 以上，高付加価值 オフィスは 0.259 以上の各 5 名にインタビュー調査を実施すること となった。

\section{4 ）インタビュ一実施者のサンプリングに関する統計的検証}

ここで各オフィス選考者の抽出結果の適切さについて，正規混合 分布モデルによる潜在クラスター分析注3）を用いて統計的に検証し ておく。この分析はデータの分布を複数の正規分布から抽出標本が 混在した状態と仮定して, 潜在的な多母集団に関する母数および各 個体がどの母集団に帰属するかを推定するものである。分析には相 関係数を $\mathrm{z}$ 変換したデータを用いた。両オフィスとも母集団数を 2 群〜 6 群として分析を試みたところ，ミニマムオフィスにおいては 3 群〜 6 群, 高付加価值オフィスにおいては 3 群, 5 群, 6 群を仮 定した場合に不適解にならずかつ識別力を有する主4) 分析結果とな った。そのうちミニマムオフィスにおいては 3 群〜 6 群, 高付加価 值オフィスにおいては 3 群および 5 群とした場合にはいずれも高相 関の領域に同一のクラスターが 1 つ形成されており，ミニマムオフ イスにおいては相関係数が 0.296 以上の值をとる 7 名, 高付加価值 オフィスにおいては相関係数が 0.201 以上の值をとる 13 名がこの クラスターに所属すると推定される。インタビュー実施者はすべて このクラスターに含まれる。なお高付加価值で 6 群とするとこの 13 名がさらに細分化されるという結果となる。

以上の分析結果は, 各オフィスを好む部分母集団が存在し, イン タビュー実施者は上記下線部が所属する部分母集団から抽出したも のと考えてよいことを示唆する。さらに，各オフィスを好む層を除 く層の相関係数の分布中心を推定注 5) すると, ミニマムオフィスは一 0.179, 高付加価值オフィスは-0.138 となる。インタビュー実施者の 相関係数最小值（ミニマム 0.296, 高付加価值 0.259）がこの值に対 して有意に大きいかを調 べる検定を行うと，ミニマ ムオフィスは $\mathrm{p}$ 值 $=0.026$, 高付加価值オフィスは $\mathrm{p}$ 值 $=0.053$ となった。各個人の 相関係数を求める際の標 本サイズは 19 と小さいた め標本誤差が大きいが，イ ンタビュー実施者はその 他の層の相関係数の分布

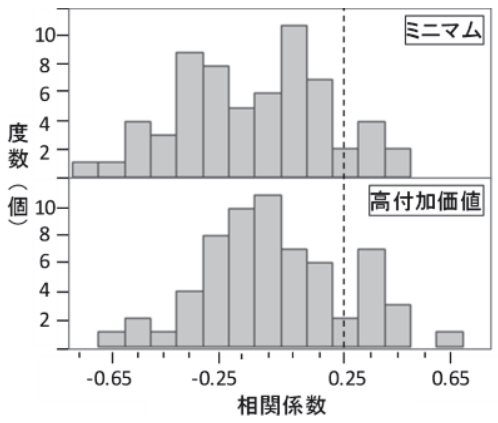

図 5 ダミー変数と選好度との相関係数 
中心に比べて，標本誤差とはみなせない程度に相関が高い人を抽出 できていることがわかる。

\section{5 ) 各オフィスを選好する層に対する評価グリッド法を実施}

3 ）で得られたミニマムオフィスを好む層から 5 名, 高付加価值 オフィスを好む層から 5 名, 計 10 名を調査対象者として抽出し, 評 価グリッド法を準用したインタビュー調査を行った。2）より評価 理由はすでに抽出済みであるため, その理由がミニマムオフィスま たは高付加価值オフィスのいずれかに該当するか確認をし，両オフ イスのいずれかに該当する評価理由の語句のみをオリジナル項目と して採用し，不明点の確認と評価理由の追加を必要に応じて行った 後, ラダーリング操作を集中的に行った。調查結果に基づき, 各個 人の評価構造図を作成し, さらにミニマムオフィスまたは高付加価 值オフィスを好む層全体でそれぞれ 1 つずつ評価構造図を作成した。

\section{3 結果と考察}

オフィス調查の結果として, 図 6 はミニマムオフィスを好む 5 名 分の評価構造図をまとめたもの, 図 7 は高付加価值オフィスを好む 5 名分の評価構造図をまとめたものを示している。

どちらのオフィスからも効率的に作業できるという項目が共通の ニーズとして抽出されているが，効率的に作業できる空間に求める 要素が異なっており, 周囲とのコミュニケーションに対する意識の 違いが見られた。職種による違いも考えられるが，ミニマムオフィ スは 1 人で作業をしたいというどちらかというとコミュニケーショ ンをあまり重視していない感がある。一方, 高付加価值オフィスは, 周りとコミュニケーションを取りながら仕事をすることでアイデア が生まれ仕事効率が上がると考えており, 周囲とのコミュニケーシ ヨンを重視している感がある。このことから，両オフィスを好む人 の特徴として，ミニマムオフィスは仕事とプライベートを区別する 人注 6), 高付加価值オフィスは楽しみながら仕事をしたい人注6) とい
うことができるのではないかと推察する。以下，それぞれのオフィ スの評価構造図から各オフィスの特徵についてさらに考察を行う。

ミニマムオフィスは「一人の空間」,「他人を意識しない」,「邪魔 されない」という項目が抽出されていることから，余計なものがな く個人のスペースが確保されていて，居心地の良さが評価されてい る。このような特徵について, 高付加価值オフィスを色彩やオブジ エで気が散ると感じる人や，一般的な島型対向オフィスを人目が気 になって集中できないと感じる人から支持を得られる可能性があり オルタナティブなオフィスとしての可能性を秘めていると推察する。 また図 6 には「BGM がある」など写真からは読み取れない項目もラダ ーダウンによって抽出されている注7)。現状で「BGM のあるミニマム オフィス」は少ないと思われ, 音量や楽曲に対する好みなどの問題 や「好きな音楽をへッドホンで聴けばよい」という考えがその背景 と推察される。しかし「BGM がある」の上位項目は「カフェのような 䨌囲気」であるから，ヘッドホンではなく空間全体をカフェのよう な雾囲気に包むための BGM が望まれる。音量・好みの問題に配慮し つつこのような主旨の BGM を導入することは, 魅力的なミニマムオ

フィス創出の手段となりうる可能性が感じられる。

高付加価值オフィスは「壁・机がカラフル」「照明がきれい」「オ ブジェがある」という項目が抽出されていることから，居心地より も見た目の良さが評価されている。また，このような空間で仕事を することによって「気分が明るくなる」,「仕事を楽しめる」,「優越 感がある」というワーカーの心理に良い影響を与えることにつなが っている。この点に関しては想定の範囲内であったが，そのことに よって「人に優しくなれる」という意外な項目も抽出されているこ とから, 高付加価值オフィスはワーカーのコンディションを良好に するだけでなく，そのことによって行動面への良い影響が期待でき ると推察する。

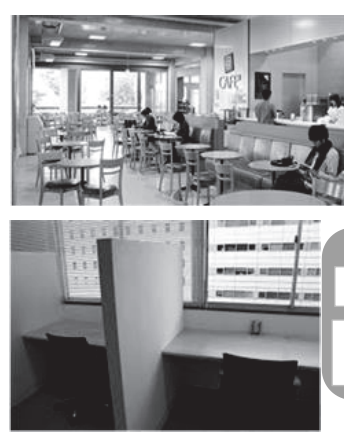

余計なことに気を遣わない:ストレスがない

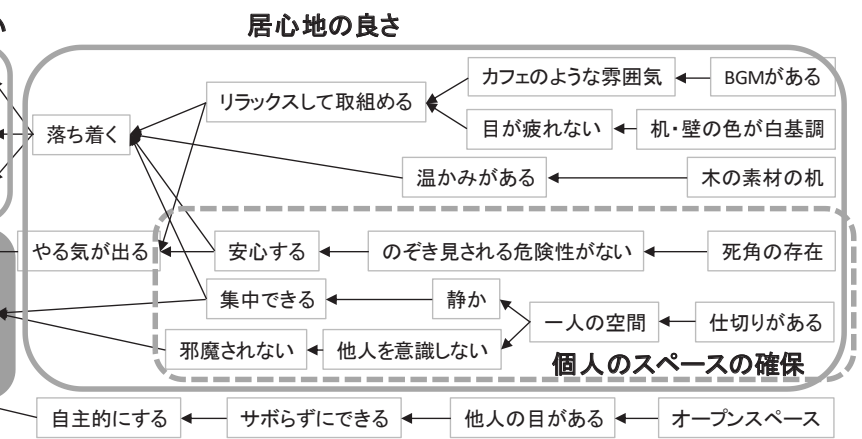

図 6 評価構造図（ミニマムオフィス）
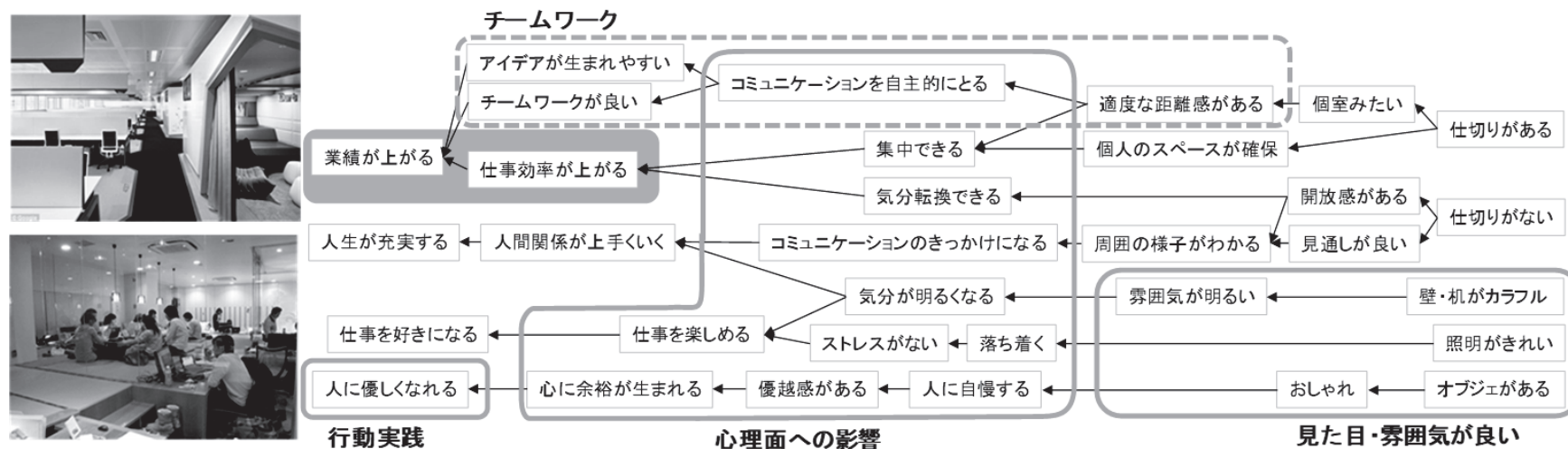

行動実践 


\section{6. ハイブリッド型の調査デザインの有効性}

\section{1 インタビュ一調査対象者の計画的サンプリング}

小島 ${ }^{11}{ }^{1)}$ によれば, 化学分野における定性分析, 定量分析のアナロ ジーから，定性調査の目的を「どんな成分（項目）が存在するか」を 漏れなく把握することと捉えた上で, 定性調查におけるサンプルサ イズについて「ある項目が抽出されるか, 否か」を問題として, 次 のような議論が展開されている。「『調査をしたならば，その項目が 抽出される人』の母比率が $\mathrm{P}$ である項目」が, $\mathrm{N}$ 人に調査した場合, その項目が 1 名も抽出されない確率 $\beta$ は，次式で表せる。

$$
\beta=(1-P)^{N}
$$

ここで， $\beta$ とは，定量的な統計的推論で言えば Type II の誤り ${ }^{12)}$ に相当するものであると考え，(式 1 )の左辺の確率を $\beta$ と表記した。 定量的な統計的推論においては, 1- $\beta$ は検出力と呼ばれ，母集団にお いて二定以上の効果があるとき，標本として得られたデータに有意 な効果がある確率を表す。転じて, 定性調査においても下線部をそ れぞれ「(一定以上の母比率で) 存在する」, 「抽出される」と置き換 えれば，1- $\beta$ は検出力と呼ばれても良いように思われる。

以上を踏まえて, 定性調査におけるサンプルサイズの参考として, 母比率 $\mathrm{P}$ と検出力 $1-\beta$ に対する必要な $\mathrm{N}$ を算出し, 表 1 を作成した。

本報における 2 つ適用事例について考える。オフィスの事例に ついて, 選好度による該当者の出現率は, ミニマムオフィス $11 \%$, 高 付加価值オフィス $19 \%$ である。この出現率に従うと, 単純な無作為抽 出によりミニマムオフィスを好む人が，検出力 $95 \%$ の確率で抽出さ れる調查を行うためには，26 名に調查を実施しなければならない。 同様に, 高付加価值オフィスの場合においては, 15 名に調査を実施 しなければならないことになる。

庭空間の事例においては, 選好度によるクラスターの構成比は, $(\mathrm{C} 1: \mathrm{C} 2: \mathrm{C} 3: \mathrm{C4}: \mathrm{C} 5: \mathrm{C6})=(18 \%: 17 \%: 14 \%: 16 \%: 13 \%: 14 \%)$ である。本事例の 場合は，全てのクラスターの出現率を同時に考慮するため，（式 1) のような簡単に書き下せる式にならないため, この出現率に従って シュミレーションを行った。庭の調查と同様 15 名を無作為抽出する シミュレーションを 1000 回行った。その結果, 全てのクラスターか ら少なくとも 1 名が抽出されたのは 546 回であった。つまり単純な 無作為抽出により 1000 名程度に評価グリッド法を実施した場合, 調 查対象者から外れるクラスターが生じる確率が 4 割を超えることに なる。

\section{2 インタビュ一調査の負担軽減}

評価理由を抽出することで評価グリッド法を行う前にある程度才 リジナル項目を抽出でき，一から評価グリッド法を始める場合と比 較してインタビューの負担はかなり軽減された。庭空間調查の事例 において，15名に対して評価グリッド法を実施したところ，インタ ビュー調查の平均的な所要時間は 1 名あたり約 15 分であった。通常 の評価グリッド法における平均所要時間は 1 名あたり約 30〜40 分 となっているため, インタビュー調査の時間を短縮できたと言える。

\section{3 定型自由記述による評価項目の検証・補完}

図 2 , 図 3 のようにインタビュー調査自体の実施者数が少ない場 合でも, アンケート調查における定型自由記述データを用いてイン タビュー調査で得られた項目がどの程度共有されているか確認する ことが可能である。また，本論文の事例では行っていないが，定型 自由記述によって得られた項目をインタビュー結果に追加し, 評価
構造図をさらに充実させることも可能と思われる。

\section{4 事前クラスター化による評価構造の把握のしやすさ}

個人別の評価構造図を作成した後, 評価構造の項目を集約して, 複数名分の評価構造図を 1 つまとめるという作業を行う。このよ うな作業は評価グリッド法を用いた調査において，結果を示寸際に 一般的に行われているものである。先に示した図 2 と図 3 は庭空間 調査の事例において, 評価構造の項目を集約してクラスターごとに

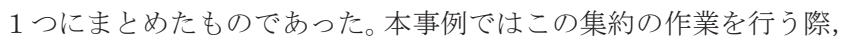
アンケート調査によって抽出された選好度評価と評価理由の結果か ら，どのクラスターに属している評価者はどのように評価をする傾 向があるという情報（以下，クラスター情報とする）をある程度把 握した上で行ったため, クラスターごとの特徵を読み取りやすく, クラスターごとに評価構造図を 1 つまとめるという作業をスムー ズに行えたように感じた。通常は, 事前にアンケート調査によって 選好度評価と評価理由の抽出などを行わず，すなわちクラスター情 報を持たずに評価構造の項目を集約する作業が行われるが，そのよ うな状況においても果たしてクラスターごとの特徵が現れるような 1 つの評価構造図を作成できるのか，気になるところである。

そこで，本報では，庭空間調查の事例を用いて，クラスター情報 がある状態で調查者が行った項目集約およびクラスターごとの評価 構造図の作成とは別に, クラスター情報がない状態でも同様の作業 を行い, 結果を比較した。調査者とは別の研究協力者 8 名注8)に依頼 して, クラスター情報を開示せずに, 庭空間調查において得られた, 外れクラスターを除外した 14 名分の評価構造の項目を集約して, 評 価構造図を 1 つによめるという作業を行った。この際, 項目の数 が多いため, 調査者によって事前に, 外れクラスターを除外した 14 名分の評価構造の項目を下位 $\Leftrightarrow$ 上位（『物理的状態』『感覚的印象』 『具体的行動』『心理的ベネフィット』）の 4 つの成分に分割すると いう作業注9) を行った後に, 研究協力者 1 名につき 1 つの成分を担 当するという形式で項目の集約を行った。作業手順について, まず, 各自で担当する成分の項目を集約する。次に，4つの成分で 1 セッ 卜となるよう，それぞれ別の成分を担当した 4 名ずつでグループを 編成する。ここでは，2つのグループが編成された。そして，各自 で集約した項目を持ち寄り,グループで1つの評価構造図を作成す る。

クラスター情報ありの状態で集約された項目群が 1 パターン，ク ラスター情報なしの状態で集約された項目群が 2 パターン得られた ところで，分析に進む。回答者 $(i) \times$ 集約後の項目 $(\mathrm{j})$ の 0-1 型デー 夕行列 (回答者 (i) が項目 (j) に該当する項目を持っている場合は 1 ,

表 1 母比率 $\mathrm{P}$ と検出力 $1-\beta$ に対する必要な N（調査人数）

\begin{tabular}{|c|r|r|r|r|r|r|r|r|}
\hline 検出力 & \multicolumn{7}{|c|}{ 母比率P } \\
\cline { 2 - 9 } $1-\beta$ & $10 \%$ & $20 \%$ & $30 \%$ & $40 \%$ & $50 \%$ & $60 \%$ & $70 \%$ & $80 \%$ \\
\hline $50 \%$ & 7 & 4 & 2 & 2 & 2 & 1 & 1 & 1 \\
\hline $45 \%$ & 8 & 4 & 3 & 2 & 2 & 1 & 1 & 1 \\
\hline $40 \%$ & 9 & 5 & 3 & 2 & 2 & 2 & 1 & 1 \\
\hline $35 \%$ & 10 & 5 & 3 & 3 & 2 & 2 & 1 & 1 \\
\hline $30 \%$ & 12 & 6 & 4 & 3 & 2 & 2 & 2 & 1 \\
\hline $25 \%$ & 14 & 7 & 4 & 3 & 3 & 2 & 2 & 1 \\
\hline $20 \%$ & 16 & 8 & 5 & 4 & 3 & 2 & 2 & 2 \\
\hline $15 \%$ & 19 & 9 & 6 & 4 & 3 & 3 & 2 & 2 \\
\hline $10 \%$ & 22 & 11 & 7 & 5 & 4 & 3 & 2 & 2 \\
\hline $5 \%$ & 29 & 14 & 9 & 6 & 5 & 4 & 3 & 2 \\
\hline
\end{tabular}


持っていない場合は 0 とする）を計 3 パターン作成して，それぞれ 数量化而類を適用した。第 7 次元までのサンプルスコアを用いて分 散分析を行い, クラスターの寄与率 $\mathrm{R}^{2}$ を求めて, 図 8 を作成した。 第 $\mathrm{K}$ 次元までのクラスターの寄与率 $\mathrm{R}^{2}$ を次式にて定義する。

$$
R^{2}{ }_{K}=\frac{\sum_{1 \leqq k \leqq K} S S B_{k}}{\sum_{1 \leqq k \leqq K} S S T_{k}} \quad \cdots(\text { 式 } 2)
$$

ここに

$$
\begin{aligned}
& S S W_{k}: \text { 第 } \mathrm{k} \text { 軸スコアのクラスター内平方和 } \\
& S S B_{k}: \text { 第 } \mathrm{k} \text { 軸スコアのクラスター間平方和 } \\
& S S T_{k}: \text { 第 } \mathrm{k} \text { 軸スコアの総平方和 } \\
& ※ S S T_{k}=S S W_{k}+S S B_{k}
\end{aligned}
$$

図 8 より, クラスター情報ありのほうが，クラスター情報なしよ りも寄与率 $\mathrm{R}^{2}$ が高い結果となった。この結果から, 事前クラスター 化は，評価グリッド法の結果の理解や解釈の面で有用な情報を提供 していると言える。一方, クラスター情報なしの場合について, こ のとき寄与率 $\mathrm{R}^{2}$ が比較的高いという結果になれば，これは「選好度 が似ている人同士だと評価グリッド法によって抽出される項目に類 似性がある」ということになる。しかし，本事例での検討の結果， 寄与率 $\mathrm{R}^{2}$ は低く，上記仮説は支持されなかった。このことは，川瀬 $ら^{13)}$ 小川ら ${ }^{14)}$ の検討結果とも一致する。

また，クラスターの効果が全くない場合，SST，SSB，SSW は区別 なく自由度（dfT, dfB, dfW とする）に比例した大きさの期待值を とり, $\mathrm{F}$ 統計量 $=(\mathrm{SSB} / \mathrm{dfB}) /(\mathrm{SSW} / \mathrm{dfW}) \fallingdotseq 1, \mathrm{R}^{2}=\mathrm{SSB} / \mathrm{SST} \fallingdotseq \mathrm{dfB} / \mathrm{dfW}$ と なる。本事例の場合, $\mathrm{SSB} / \mathrm{SST} \fallingdotseq 5 / 13 \fallingdotseq 0.38$ となる。

数量化恧類における後の方の軸が意味ある情報を持たない雑音成 分であるとすれば，後の方の軸の成分が加わるにつれて $\mathrm{R}^{2}$ は 0.38 に近づくことになる。クラスター情報なしの結果は, 第 7 軸までで わずかに 0.4 を上回っているものの，0.38 とかなり近い值である。 一方, クラスター情報ありの結果は, 第 4 軸以降は軸の数が増える とともに $\mathrm{R}^{2}$ が漸減する（雑音成分が混ざっていくためと思われる） が, 第 3 軸までは明らかに 0.38 より大きい值である。数量化亚類に おける最初の方の軸（主要な個人差を表寸軸）にクラスター間の違 いが現れていると言える。さらに，「クラスター情報なし(a)」の最 初の方の軸の $\mathrm{R}^{2}$ は, 当然あるべき統計的なばらつきに比べても「ク ラスター差がない」ように見える。これは項目集約作業時の意識と して，「回答者の類型化」や「個人差の表現」ではなく，むしろ「最 大公約数的に多くの回答者の評価構造を吸収しうる共通の出力」を

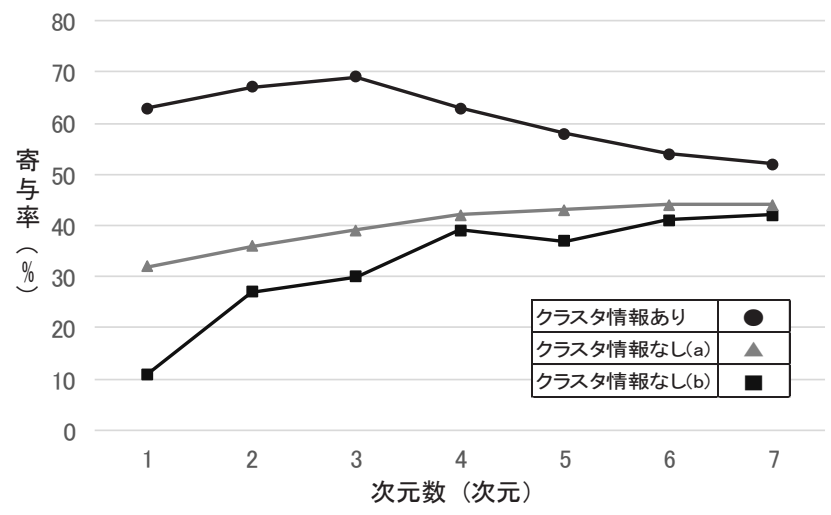

図 8 数量化正類のスコアに対するクラスターの寄与率
目指そうとした結果かもしれない。通常の評価グリッド法の結果を まとめるときには個人差より最大公約数的共通を目指すことも多い

以上より，結果をまとめるときにクラスター情報を開示するか否 かは調査の目的によって使い分けるということも考えられる。類型 化や個人差を把握したい場合は, 結果集約作業はクラスター情報を 開示して行う。一方で, 共通構造を把握したい場合は, 結果集約作 業は調查の時間やコストなど諸般の事情が許寸場合においては，イ ンタビュアーとは別の研究協力者がクラスター情報を伏せて行うほ うが良いと思われる。

本節の検討結果は, クラスター情報あり・なしで評価構造図の解 釈がどの程度異なるかという参考情報の 1 つにならう。この種の定 性調査を用いた研究の更なる発展のために役立つ情報が得られたの ではないかと考える。

\section{7. まとめ}

\section{1 ハイブリッド型の調査デザインの特徵}

本報では，評価グリッド法におけるハイブリッド型の調査デザイ ンを提案し，以下のような長所を有することを示した。

\section{(1)インタビュー調査対象者の計画的サンプリング}

(2)インタビュー調査の負担軽減

(3)定型自由記述による評価項目の検証・補完

(4)事前クラスター化による評価構造の把握のしやすさ

本報の提案の主旨は，(1)より評価構造が類似することが期待され る対象者の層を定量調査によりまず作成し, 計画的に評価グリッド 法の調査対象者を選定することにある。評価グリッド法の調查対象 者を計画的にサンプリングすることで，調査結果の網羅性・代表性 を確保した。(2)(3については，本報の第一の目的ではないが，副次 的な長所として期待していたことである。そして，実際に調査を行 ってみた結果, インタビューの所要時間を概ね $1 / 2$ に短縮でき (2)), 定型自由記述式アンケート調査のデータからインタビュー結果の一 般性を確認できた（(3)）。(4)については，実際に調査を行ってみて初 めて実感したことであり，6．4節でささやかな検証を行っている。 本報で提案した手法が普及するためには，調查者が直接実感でき るような長所が必要である。しかしながら，(1)の効用を調查者が実 感することは難しいかもしれない。通常，定性調査においては「ど んな情報を抽出することができなかったか」を実感しにくい。サン プリングが網羅性を欠き，そのために抽出できなかった情報があっ たとしても，「抽出できた情報」の中に有用な知見があり調查結果に 満足した場合，サンプリングを改善しようというモチベーションは 得にくいのではないかと思われる。一方，(2)～(4)は調査者が直接実 感することができる長所である。実感できる長所があるということ は，本手法の今後の普及に大いに役立つと思われる。

\section{2 今後の課題および展望}

本報では, アンケート調査を行った後に，インタビュー調查を行 うという， 2 段階の評価グリッド法を提案した。また，本報ではイ ンタビュー調査の負担を軽減するために，インタビュー調査につい てはラダーリングに重点を置いて行ったが，その他にも，評価グリ ッド法を 2 段階構成にしたことでインタビュー調查については様々 なバリエーションが考えられる。本事例では 2 つのオフィスタイプ ごとにそれぞれの魅力を把握するととともに，両者の相違も把握し 
たかったため, インタビュー調査の内容をオフィスタイプ別に大き く変えるということはしなかった。しかしながら，タイプごとの魅 力に関する抽出力を高めることができれば，同じ方法による相違の 把握はできなくてもよいという立場もありうる。その場合，例えば ミニマムオフィス選好層に対するインタビュー調査においては，ミ ニマムオフィスに該当するエレメントを追加して通常の手順で一か ら評価グリッド法を開始するという方法が考えられる。その際，追 加のエレメントは調査者が用意するだけでなく, これまでの経験に 基づくリアルな評価を抽出するために，対象者にその場面を想起し てもらい評価対象とするなど，様々なバリエーションが考えられる。 インタビュー調查部分をどのように扱うかについては調查の目的に よって使い分けることが可能であり, そのような事例の検討・報告 については今後の課題とする。

\section{謝辞}

本研究を行うにあたり, JSPS 科研費（JP16K14350）により費用の 一部を支出した。本報の調査のうち, 庭に関する調査は鳥島修平氏 （当時早稲田大学人間科学部卒論生, 現所属（株）タカショ一)，オ フィスに関する調查は松尾賢介氏と鈴木雄介氏（当時早稲田大学人 間科学部卒論生）が中心となって実施したものである。今後の課題 とした部分の一部は，2016 年の日本建築学会大会学術講演会にて讃 井純一郎先生からいただいたコメントを参考にさせていただいた。 本研究にご協力・ご助言いただいた全ての皆様に謝意を表します。

注 1 ）本報は，既報 ${ }^{11)}$ 2) をもとに分析・考察を追加し，再編したものである。 注 2 ) ミニマムオフィスの写真について, 選好度評価の結果および評価理由の 記述内容より, 回答者にミニマムオフィスとして捉えられていない写真が 1 枚あると判断したため, 選好度評価との相関係数を求めるときにその 1 枚 は除外した。以後の調查では, オフィス写真は 19 枚としている。

注 3$)$ 相関係数の標本分布はフィッシャーの $\mathrm{z}$ 変換 $: \mathrm{z}(\mathrm{r})=\ln [(1+\mathrm{r}) /(1-\mathrm{r})]$ に より, 母相関の值によらず分散 $1 /$ ( N-3) の正規分布に近似的に従う。混合正 規分布モデルの推定には HAD15.106（清水 ${ }^{15)}$ ) を用いた。

注 4 ) 高付加価值で 4 群とすると, 構成比率 0 と推定される母集団が生じた (不適解)。両オフィスとも 2 群とした場合には推定される 2 つの集団分 布の重なりが大きい結果となった（従って各個体のどの母集団に帰属する かの識別力が低い)。

注 5 ) 相関係数の分布中心は, $\mathrm{z}$ 変換值の平均值の逆 $\mathrm{z}$ 変換值として求めた。 ここでの検定は「帰無仮説：母相関係数=上記分布中心值」の下で得られる $\mathrm{N}=19$ の標本相関係数 $\mathrm{z}$ 変換值の標本分布が分散 $1 /$ ( N-3) の正規分布に従う ものとして, 片側 $\mathrm{p}$ 值を求めている。

注 6 ) これらはインタビュー回答者が言及した内容である。ミニマムオフィス 選好層の「仕事とプライベートを区別したい」というニーズは階層的な評価 構造において特定の下位項目を持つオフィス評価項目として位置づけにく いため図 6 には示してないが，その回答者の働き方に関する喍好を表す情 報であり, ワーカー像を考える上で参考になる。一方，高付加価值オフィス 選好層の「楽しみながら仕事をしたい」というニーズは図 7 の評価構造図に
も「仕事を楽しめる」という項目として表現されている。

注 7 ) 評価グリッドにおいて, 提示するエレメントは評価のきっかけにすぎず, エレメントから読み取れないこともラダーリングにより抽出される場合が ある。その性質は, エレメントの選定における漏れや偏りに対する頑健性, および現状の当該対象環境においては実現されていないニーズ項目を抽出 できる可能性という点で，評価グリッド法のメリットの一つであると考光 られる。

注 8 ) 研究協力者 8 名は, 評価グリッド法や自由記述データを分類する作業の 訓練を受けている。

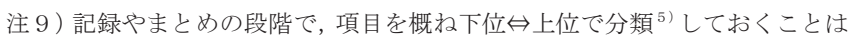
一般的に行われている手続きである。

\section{参考文献}

1）小島隆矢, 彭博：評価グリッド法のより効率的な調査デザインに関する 一提案, 日本建築学会大会学術講演梗概集, 環境工学 I, pp. 103-104, 2015. 9

2 ）彭博，小島隆矢：評価グリッド法におけるハイブリッド型の調査デザイ ンの検討, 日本建築学会大会学術講演梗概集, 環境工学 I, pp. 163-164, 2016. 8

3) 彭博, 小島隆矢：評価グリッド法・レパートリーグリッド法・定型自由 記述の説明力比較, 環境心理評価における定性調查手法の研究, 日本建築 学会環境系論文集, No. 726, pp. 661-668, 2016. 8

4) 讃井純一郎, 乾正雄：レパートリー・グリッド発展手法による住環境評 価構造の抽出, 認知心理学に基づく住環境評価に関する研究 1 , 日本建築 学会計画系論文報告集, No. 367, pp. 15-22，1986．9

5 ) 日本建築学会：住まいと街をつくるための調査のデザイン，インタビュ ー/アンケート/心理実験の手引き，オーム社，2011．3

6 ）日本建築学会：よりよい環境創造のための環境心理調査法入門, 技報堂 出版, 2000. 5

7 ) 伊丹弘美, 小島隆矢：人材の確保・活用におけるオフィス環境の寄与に 関する研究：その 1 , 大学生が働きたいと思うオフィスの評価構造, 日本 建築学会大会学術講演梗概集, 環境工学 I, pp. 123-124，2013.8

8 ) 庭写真: http://takasho. co. jp/ (参照 2014. 10. 23)

9 ) 平手小太郎, 小島隆矢, 川井敬二：選定者自身の言葉を用いた環境評価 手法：その 5 , 個人別 $\mathrm{KJ}$ 法的分類デー夕の分析, 日本建築学会大会学術 講演梗概集，D-1，環境工学 I， pp. 747-748，1999．7

10 ）オフィス写真：http://www. shigotoba. net/ (参照 2012.11.15), http://www. jsbc. or. jp/spacers/index. html（参照 2012.11. 15), http://www. hongkiat. com/blog/creative-modern-office-designs（参照 2012. 11. 15), http://www. hello-office. net/about/ (参照 2015. 10. 26)

11 ) 小島隆矢：質的データは量的データに勝つか?（統計と表現におい て)：建築環境心理学の立場から, 日本行動計量学会大会発表論文抄録集, No. 35 , pp. 179-182, 2007. 9

12 ) 永田靖：サンプルサイズの決め方, 朝倉書房, 2003。9

13 ）川瀬亮, 小川遼, 大澤昭彦, 大野隆造：写真評価に基づく環境評価構 造の類似度判定, 戸建住宅設計における施主の潜在的要求の抽出に関す る研究その 1 , 日本建築学会大会学術講演梗概集, 環境工学 I, pp. 3132, 2013. 8

14 ）小川遼, 川瀨亮, 大澤昭彦, 大野隆造：写真評価に基づく環境評価構 造モデルの補完，戸建住宅設計における施主の潜在的要求の抽出に関寸る 研究その 2 , 日本建築学会大会学術講演梗概集, 環境工学 I, pp. 33-34, 2013. 8

15 ) 清水裕士：フリーの統計分析ソフト HAD, 機能の紹介と統計学習・教 育, 研究実践における利用方法の提案, メディア・情報・コミュニケーシ ヨン研究，第 1 巻，pp. 59-73，2016. 3 
A STUDY ON THE HYBRID DESIGN OF RESEARCH FOR EVALUATION GRID METHOD

A study on qualitative research for getting evaluation term Part2

\section{Bo PENG ${ }^{* 1}$ and Takaya KOJIMA*2}

${ }^{* 1}$ Grad. Student, Grad. Sch. of Human Sciences, Waseda Univ., M.A. in Human Sciences

${ }^{*}$ Prof., Faculty of Human Sciences, Waseda Univ., Dr.Eng.

Qualitative research, including evaluation grid method, has long been recognized as important in the field of environmental psychology. In this study, we have endeavoured to make use of each research method as more effective, explaining the characteristics of each research method and also improving each research method to make it more efficient in its use.

The focus of the previous paper was on three research methods: evaluation grid method, repertory grid method, or triadic procedure technique, and typical free description. To explain the difference between these three research methods, comparison study on the interpretability, or effectiveness of evaluation terms extracted from the three research methods was conducted. The result showed that evaluation grid method had high interpretability, triadic procedure technique had moderate interpretability and typical free description had low interpretability.

Based on the previous paper, the focus of this paper is on evaluation grid method which has high interpretability and typical free description which has low interpretability but can conduct research on a large sample. This paper proposes the research method which selects the best of both research methods and which is called the hybrid design of research for evaluation grid method.

The procedure of the hybrid design for evaluation grid method is done by using a questionnaire. Subsequently, an interview is conducted. By using the result of the questionnaire, a group of people with the same opinions is formed. Afterwards the people to do an interview from the group are selected. There are two types when selecting the people to do an interview. When the study needs a wide range of diverse opinions, it should be selected several people from each group. When the study needs an opinion from a specific standpoint, it should be selected the people from several groups or one group not from each group. In this report, introducing two cases of selecting the people to do an interview to show the effectiveness of the hybrid design for evaluation grid method.

The hybrid design for evaluation grid method has three merits: 1) sampling a target person of interview, 2) reducing interview time, 3) inspecting and completing evaluation terms by the date of typical free description and 4) being easier facilitating the interpret evaluation structures. In order to spread the hybrid design for evaluation grid method, it must contain the merits which the researchers can realize directly. From this point of view, 1) is not realized directly but 2),3) and 4) are implemented directly. The hybrid design for evaluation grid method not only has the merits of 1) but also has the merits of 2),3) and 4) is expected to benefit researchers. 